\title{
MENAKAR TEOLOGI KEADILAN DALAM POLIGAMI
}

\author{
Subehan Khalik \\ Fakultas Syariah dan Hukum UIN Alauddin Makassar \\ Subehan.khalik@uin-alauddin.ac.id
}

\begin{abstract}
As a law passed by God, polygamy has transedental elements that often cause various interpretations. In this context, polygamy creates a new atmosphere for restoring the values of justice in its practice of law. If men are responsible for their actions as per the Qadariyah group's thinking, then polygamy should provide justice for women. However, if polygamy means the prerogative of God to bring down the law, then the demands of justice in this act cannot be brought forward because the law has become the absolute will of God.
\end{abstract}

Keywords: Theology, Polygamy, Justice

\section{A. LATAR BELAKANG MASALAH}

Asma Barlas dalam bukunya berjudul "Believing Women in Islam, mengurai berbagai hal berkaitan eksistensi perempuan dalam Islam. Asma memulai paparannya dari kepentingan Tuhan untuk berpihak kepada laki-laki dan pertanyaan mengenai apakah Alquran berbasis patriarkal atau misoginis dan apakah ketidaksetaraan gender dalam kehidupan adalah hasil dari pengambil alihan peran ilmu pengetahuan dan hukum oleh Alquran, adakah kesetaraan gender dalam Alquran dan beberapa pertanyaan lain yang mengemuka. Hal ini dilandasi oleh kekalutannya melihat fakta bahwa di beberapa Negara Islam, ternyata perempuan tidak memiliki hak sebagaimana mestinya dan cenderung menjadi komoditas. ${ }^{1}$

Pada aspek lain, teologi keadilan yang dikemukakan oleh aliran teologi Mu'tazilah mengisyaratkan bahwa Tuhan akan berbuat adil kepada hamba-Nya, maka diberikanlah kekuasaan kepada si hamba untuk memilih perbuatan untuk dipertanggungjawabkan. Karena mustahil bagi Allah untuk berbuat sesuatu untuk diri-Nya sendiri, melainkan berbuat sesuatu untuk kebaikan hamba-Nya dan untuk kebaikannya. ${ }^{2}$ Dalam konteks keadilan terbangun asumsi bahwa Allah akan berlaku adil kepada segenap manusia tanpa harus membedakan jenis kelamin dan fungsi seksualitas mereka. Prinsipnya, keadilan Tuhan akan memberi eksistensi yang sama antara lelaki dan perempuan tanpa ada diskriminasi antara keduanya.

${ }^{1}$ Asma Barlas, Believing Women in IslamUnreadingPatriarchal Interpretation of The Qur'ān (Cet. I; United States Of America: University of Texas Press, 2002), h.

${ }^{2}$ Harun Nasution, Teologi Islam; Sejarah, Analisa Perbandingan (Jakarta: UI Press, 1989), h. 122; Ahmad Amīn, Duhā al-Islām Juz III (Mesir: Maktabah al-Nahḍah, t.th), h. 44. 
Kehadiran ayat tentang poligami dalam QS. Al-Nisa/3:3 mengurai masalah baru dalam disharmoni antara peran lelaki dengan perempuan dalam konteks status, fungsi maupun peran. Guna menguji kembali teologi keadilan dalam perintah poligami sebagaimana difahami dari Alquran, tulisan ini akan mengulas bagaimana menakar teologi keadilan dalam Poligami dengan sub masalah:

1. Bagaimana Konteks Keadilan dalam perbuatan manusia

2. Bagaimana Hakekat Keadilan Teologis dalam Poligami

\section{B. TEOLOGI KEADILAN DALAM PERBUATAN MANUSIA}

Perbuatan manusia dalam teologi adalah kajian yang terus menerus melahirkan persinggungan pendapat dalam kelompok besar aliran Jabariyah dan Qadariyah. Bahkan dalam aliran teologi Jabariyah pun, perbuatan manusia menjadi kajian yang berbeda sebagaimana dalam Asy'ariyah dan Maturidiyah. Konteks ini memberi gambaran bahwa perbuatan manusia menjadi sentra pengukur dari adil-tidaknya Tuhan terhadap hamba-Nya. ${ }^{3}$

Dua kelompok utama dalam arus pembicaraan tentang perbuatan manusia dan keadilan Tuhan adalah Jabariyah dan Qadariyah. Kedua mainstream ini mengukur kadar perbuatan manusia dari sisi siapa agen dari keseluruhan perbuatan itu dan apakah manusia sebagai pelaku dapat dimintai pertanggung jawaban dari perbuatannya. Bagi kelompok Jabariyah yang fatalistik, perbuatan manusia itu tidak lahir dari diri mereka sendiri. Itu sebabnya, manusia dipandang hanya sebagai objek yang digerakkan seperti wayang. ${ }^{4}$ Pandangan kalangan Jabariyah ini didasari atas faham kehendak mutlak Tuhan, sehingga dalam perbuatan manusia Tuhan tetap berkehendak mutlak, termasuk pada perbuatannya. ${ }^{5}$ Konteks berbeda dikemukakan oleh kalangan Mu'tazilah yang mewakili kelompok Qadariyah dengan menyatakan bahwa manusia berhak menentukan segala macam perbuatannya, manusia memiliki kebebasan dalam menentukan perbuatannya dan dengan demikian, Tuhan tidak ditempatkan sebagai Tuhan yang memiliki kekuasaan absolut. ${ }^{6}$ Menurut $\mathrm{Mu}^{\prime}$ tazilah, keadilan Tuhan telah menempatkan diri-Nya sebagai Tuhan yang memiliki batas absolutisnya, sehingga Tuhan kemudian terikat oleh hukum-hukum yang telah diciptakan-Nya yang didapati dalam sunnatullah-Nya.

Mainstream dalam teologi Islam telah menempatkan Tuhan sebagai Tuhan yang berkehendak mutlak (Versi Jabariyah) sehingga perbuatan manusia tidak dianggap sebagai perbuatan mereka sendiri meski dalam kajian selajutnya, kalangan Asya' ari mengeluarkan konsep yang dikenal dengan "al-kasb", namun dalam pandangan ahli, konsep ini tidak juga menggambarkan bahwa Tuhan telah memberikan kebebasan mutlah kepada manusia dalam konteks perbuatan.

\footnotetext{
${ }^{3}$ Teori perbuatan manusia dikenal dalam kajian " $a l-k a s b$ ” efek dari diskursus tentang perbuatan manusia melahirkan teori tentang keadilan Tuhan. Lebih lanjut lihat; Harun Nasution, Teologi Islam; Sejarah, Analisa Perbandingan (Jakarta: UI Press, 1989), h. 108-122.

${ }^{4}$ Harun Nasuiton, Teologi Islam; Sejarah, Analisa Perbandingan (Jakarta: UI Press, 1989), h. 108

${ }^{5}$ Muhammad Ibn al-Karīm al-Syahrastān̄̄, al-Milal wa Nihal (Beirūt: Dār al-Fikr, t.th), h. 236.

${ }^{6}$ Harun Nasution, Teologi Islam (Jakarta: UI Press, 1998), h. 108
} 
Sebaliknya kelompok Mu'tazilah yang mewakili kalangan Qadariyah memandang bahwa manusia telah diberi kebebasan mutlak dalam menentukan perbuatan mereka. Bagi Mu'tazilah, Tuhan telah membatasi diri-Nya dengan keadilan-Nya sehingga Tuhan tidak akan turut serta dalam perbuatan manusia sebab keadilan Tuhan akan berimplikasi pada pembalasan.

Keadilan Tuhan dalam pandangan Qadariyah bermakna Absolutisme Tuhan telah larut dalam kebebasan manusia dalam berbuat. Konteks ini akan mengaitkan dua sisi dalam beragama yaitu sisi Ke-Tuhanan dan sisi Kemanusiaan. Dikatakan demikian sebab agama telah memiliki dua sisi penting dalam menjadikannya sebagai alat menuju Tuhan dan bukan sebagai tujuan. Penilaian yang kuat terhadap perbuatan manusia juga menandakan bahwa Tuhan telah menempatkan aspek kemanusiaan dalam menunjukkan jalan manusia menuju kepada-Nya. Dengan demikian kesalehan dalam agama, sesungguhnya adalah kesalehan yang tidak mengenyampingkan aspek kemanusiaan dalam perbuatan dan tujuan perbuatan itu. Ringkasnya dapat dikatakan bahwa keadilan dalam agama akan tercipta jika jalan kepada Tuhan ditempuh tanpa mengabaikan sisi kemanusiaannya.

Keadilan dalam konteksnya memiliki empat cakupan pengertian sebagai berikut :

1) Keadilan dalam Konotasi "Sama-Rata" sebagaimana difahami dari QS. AlNisā/4 : 58 sebagai berikut :

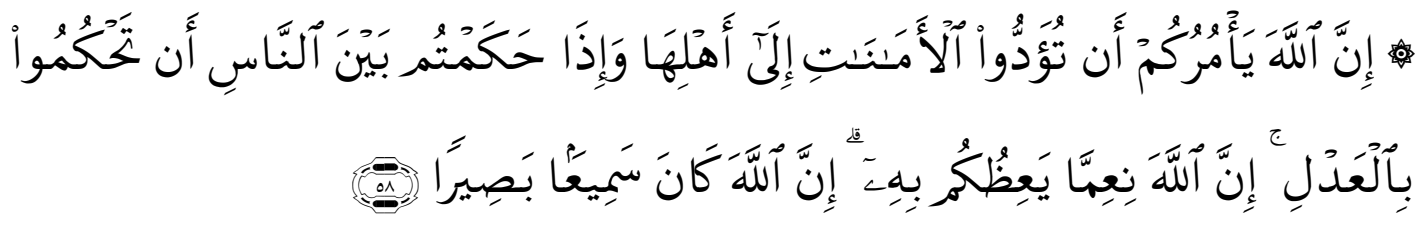

Terjemahnya :

Sesungguhnya Allah menyuruh kamu menyampaikan amanat kepada yang berhak menerimanya, dan (menyuruh kamu) apabila menetapkan hukum di antara manusia supaya kamu menetapkan dengan adil. Sesungguhnya Allah memberi pengajaran yang sebaik-baiknya kepadamu. Sesungguhnya Allah adalah Maha mendengar lagi Maha melihat. ${ }^{7}$

Makna adil dalam ayat ini difahami sebagai persamaan dalam perlakuan dan tidak ada perbedaan antara satu dengan lainnya sebagaimana difahami dalam riwayat yang menunjukkan bahwa ayat ini turun pada saat Rasulullah saw. sedang melaksanakan haji wada'. Saat itu Rasulullah mengemukakan bahwa manusia itu tidak boleh dibedakan karena status sosial dan ukuran kemuliaan seseorang itu terletak pada ketakwaannya. ${ }^{8}$

\footnotetext{
${ }^{7}$ Kementrian Agama RI. Alquran dan Terjemahnya (Semarang: Toha Putera, 2014), h. 128

${ }^{8}$ Lihat al-Zamaskhsyarī, Al-Kasysyāf 'an Haqāiq Gawāmid al-Tanzīl wa 'Uyūn al-Aqāwil fì Wujūh al-Ta 'wīl, Juz III (Mesir: Dār al-Kutub al-'Ilmiyyah, 1998), h. 2; Ibnu Hisyām, Sirah al-Nabawiyah (Kairo: Dār al-Tawfiqiyah, 1975), 354. Lihat pula Khadijah al-Nabrāwī, Mawsūah al-Huqūq fì al-Islām (Mesir: Dār al-Salām, 2006), h. 289.
} 
2) Adil dalam makna "keseimbangan" difahami dari QS. Al-Infițār/82 : 6-7 sebagai berikut:

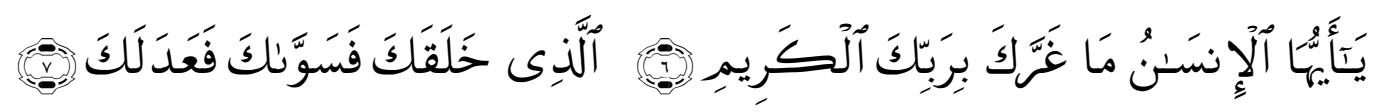

Terjemahnya :

Hai manusia, Apakah yang telah memperdayakan kamu (berbuat durhaka) terhadap Tuhanmu yang Maha Pemurah. Yang telah menciptakan kamu lalu menyempurnakan kejadianmu dan menjadikan (susunan tubuh)mu seimbang, ${ }^{9}$

Konteks adil dalam ayat ini adalah keseimbangan sebagaimana difahami dari penjelasan ayat bahwa keadilan dimaksud dengan ayat ini adalah keseimbangan sebagaimana gambaran Allah terhadap kesempurnaan penciptaan manusia yang mampu berdiri tegak karena adanya keseimbangan badan. Keseimbangan inilah yang menyebabkan manusia dapat berdiri kokoh dan tidak jatuh. ${ }^{10}$

3) Keadilan dalam makna menghormati hak pribadi dan mendelegasikan hak kepada pihak-pihak yang berkepentingan sebagaimana difahami dalam QS. Al-Nahl/16 : 90 sebagai berikut :

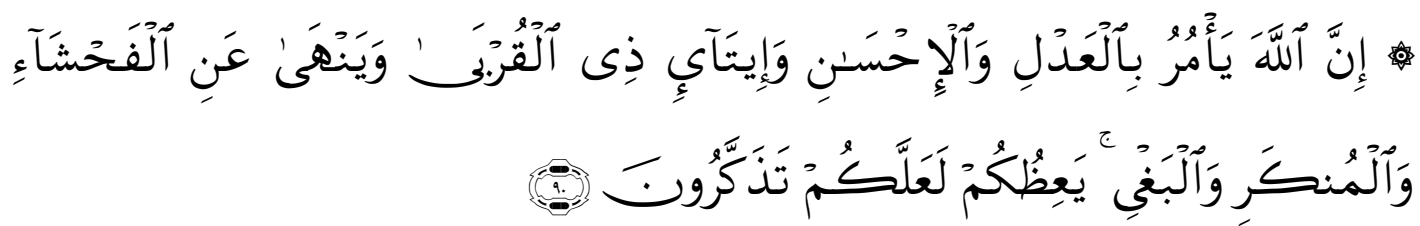

Terjemahnya :

Sesungguhnya Allah menyuruh (kamu) Berlaku adil dan berbuat kebajikan, memberi kepada kaum kerabat, dan Allah melarang dari perbuatan keji, kemungkaran dan permusuhan. Dia memberi pengajaran kepadamu agar kamu dapat mengambil pelajaran. ${ }^{11}$

Makna adil dalam konteks ayat ini adalah pendelegasian hak kepada pihakpihak yang berkepentingan. Tuntunan dalam ayat ini mengarahkan manusia untuk bersikap secara cermat terhadap hak-hak orang lain. Menurut catatan Murtaḍa Muțahhari bahwa adil dalam makna pendelegasian hak kepada yang berkepentingan meliputi makna sebagai berikut:

(1) Hak dan pemilikan dalam makna luas meliputi segala macam hak dasar dari manusia untuk hidupnya, misalnya hak untuk mendapatkan makanan untuk menopang hidup.

(2) Kekhususan hakiki manusia dalam bentuk pengakuan terhadap hak dasar untuk mendapatkan pengakuan dalam upaya pencarian jatidirinya. ${ }^{12}$

${ }^{9}$ Kementrian Agama RI. Alquran dan Terjemahnya, h. 1032.

${ }^{10}$ M. Quraish Shihab, Wawasan Alquran, Edisi Baru (Cet. II; Bandung: Mizan, 2007), h. 148.

${ }^{11}$ Kementrian Agama RI. Alquran dan Terjemahnya, h. 415.

12 Murtaḍa al-Muțahhari, al- 'Adl al-Ilāhī, terj. Ke dalam Bahasa Arab oleh Muhammad Abd alMun'im al-Khaqani (Qumm, Iran: Maṭba'at al-Khayyām, 1981), h. 66. Lihat pula Aḥmad Muștafā alMarāghī,Tafsīral-Marāghi, Jilid V, (t.t.:Dār al-Fikr,1974), h. 45. 
(3) Keadilan dalam makna sifat Allah yang tidak pandang bulu kepada hambaNya dalam menganugerahkan nikmat. Pemberian nikmat kepada hambaNya tidaklaj bersyarat sehingga nikmat dan rahmat Tuhan dilimpahkan dengan melimpah termasuk dalam hal ini penetapan berlakunya syariah (hukum) untuk kemaslahatan manusia adalah bentuk keadilan Allah kepada hamba-Nya. ${ }^{13}$

\section{TEOLOGI KEADILAN DALAM POLIGAMI}

Ditengarai kalau poligami adalah praktek berkeluarga yang telah dilak sanakan oleh bangsa Semitic yaitu bangsa leluhur dari bangsa-bangsa Arab sekarang ini. Tergambar dari praktek perkawinan Nabi Ibrahim yang menikahi Sarah setelah ragu jika Sitti Hajar istri pertamanya telah melewati masa subur (manuphouse). Praktek Nabi Ibrahim ini menurun kepada kaum Yahudi. Sementara di kalangan Nasrani praktek ini mulai dianggap sebagai larangan setelah 1563 dimana Konsili Trente masih terus berhadapan dengan pihak-pihak yang mempertahankan bahwa poligami adalah praktek perkawinan yang tidak melanggar perintah Tuhan. ${ }^{14}$ Data ini menunjukkan bahwa poligami telah memiliki landasan sosial secara praktek dalam masyarakat, namun menjadi pertanyaan kembali adalah apakah praktek semacam ini mendapat legalitas dalam hukum agama sebagai praktek biasa atau masuk dalam kategori praktek yang didaruratkan.

Poligami adalah sebuah perbuatan hukum yang dihalalkan sebagaimana difahami dari QS al-Nisā/4: 3 sebagai berikut :

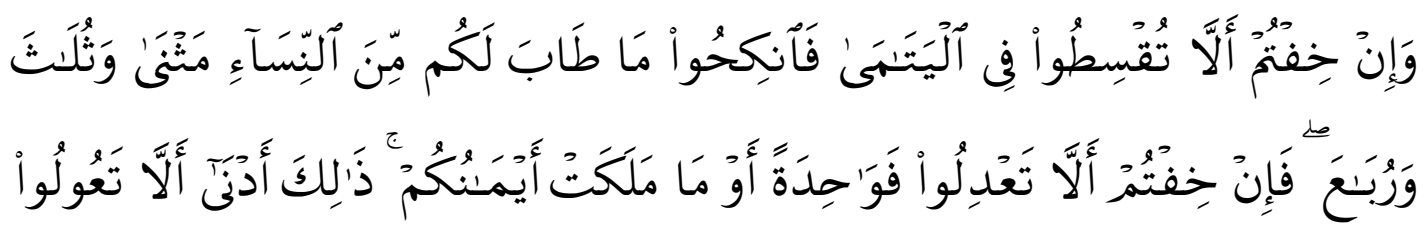

Terjemahnya:

Dan jika kamu takut tidak akan dapat Berlaku adil terhadap (hak-hak) perempuan yang yatim (bilamana kamu mengawininya), Maka kawinilah wanita-wanita (lain) yang kamu senangi : dua, tiga atau empat. kemudian jika kamu takut tidak akan dapat Berlaku adil, Maka (kawinilah) seorang saja, atau budak-budak yang kamu miliki. yang demikian itu adalah lebih dekat kepada tidak berbuat aniaya. ${ }^{15}$

Latar belakang turunnya ayat ini dijelaskan bahwa seorang laki-laki yang telah memiliki banyak istri, merasa berat menghidupi para istrinya. Maka lakilaki ini berniat untuk menikahi kembali seorang anak yatim dengan maksud memanfaatkan harta anak yatim tersebut untuk dapat menghidupi para istrinya, maka turunlah ayat ini perihal perintah untuk berbuat adil kepada anak yatim

\footnotetext{
${ }^{13}$ M. Quraish Shihab, Wawasan Alquran, h. 116.

${ }^{14}$ Ahmed E. Souaiaia, Contesting Justice Women, Islam, Law, and Society (Cet. I; New York: State University of New York Press, Albany, 2008), h. 48-49.

${ }^{15}$ Kementrian Agama RI. Alquran dan Terjemahnya, h. 115.
} 
dan menghindari mengawini mereka karena latar belakang harta mereka. ${ }^{16} \mathrm{Al}-$ Tabarī menekankan agar menghindari wanita-wanita yang disenangi jika tak mampu berbuat adil kepada mereka dan solusi yang ditawarkannya adalah dengan mendatangi para budak mereka agar mereka dapat berbuat adil kepada kaum wanita. ${ }^{17}$

Keadilan sebagaimana dikutip dalam ayat pada QS al-Nisā/4: 3 pada dasarnya merujuk kembali kepada perbuatan adil dalam distribusi, pemenuhan hak dan kewajiban dan keseimbangan. Tak ada satu alasan apapun yang dibenarkan dalam poligami jika motivasinya berbelok arah dari "keadilan" sebagai disebut dalam ayat di atas. Dalam pandangan Musda Mulia, poligami diberlakukan berdasar pada kondisi masyarakat muslim yang kalah telak dalam perang Uhud. Pada saat itu banyak laki-laki yang gugur dalam medan perang sehingga jumlah janda juga meningkat. Kondisi ini memaksa keadaan untuk menyelamatkan para janda tadi beserta anak mereka dengan melegalkan para laki-laki yang masih hidup dan telah memiliki istri untuk berpoligami. Kebolehan berpoligami mendasar untuk dilegalkan mengingat kondisi masyarakat menuntut perbuatan ini, maka dapat dikatakan jika poligami saat itu bukanlah hukum dasar melainkan hukum pilihan. ${ }^{18}$

Pada sisi lain meningkatnya jumlah anak yatim juga mendasari kebolehan para wali untuk menikahi anak-anak yatim yang ada dalam perlindungan mereka. Sekedar menjadi gambaran bahwa para anak yatim perang Uhud tidak semuanya miskin, namun sebagian mereka ada yang mampu dengan harta warisan yang cukup melimpah. Kondisi ini menimbulkan spekulasi di kalangan wali untuk menikahi mereka agar harta-harta mereka tidak berpindah tangan kepada pihak lain. Tentu saja maksud dan tujuan ini tidaklah luhur dan cenderung menderai "keadilan" yang diperintahkan dalam QS al-Nisā/4: 3 . Gelagat inilah yang kemudian dijadikan dasar sebagai unsur kehati-hatian mengijinkan poligami jika tidak menghianati rasa "keadilan" bagi wanita. 19

Konteks "keadilan" dalam kajian ini bukan semata mengarah kepada perbuatan mengatur waktu kunjungan kepada para istri dengan jadwal hari. ${ }^{20}$ Keadilan distributif semacam ini boleh jadi mewakili sebagian "keadilan" di antara para istri. Bentuk keadilan sesungguhnya adalah munculnya syarat yang ketat bagi pelaku poligami guna menghindarkan para wanita dari kejahatan terselubung pelakunya. Inisialisasi terhadap bahaya terselubung poligami ditampilkan secara vulgar dalam ayat sehingga sangat sulit bagi pelaku untuk menilai kembali ekses yang ditimbulkan dari perbuatan polgami. Sekaligus menjadi landasan pula bahwa perbuatan poligami pada hakekatnya sangat jauh dari "keadilan" jika pelakunya tidak memiliki keimanan yang kuat serta kapasitas pribadi yang paripurna. Indikator ketidak mampuan untuk berbuat adil dicantumkan pula secara jelas pada ayat "fain khiftum anlā ta'dilü

\footnotetext{
${ }^{16}$ Muhammad Rāsyid Riḍa, Tafs̄̄r al-Manār vol.4 (Beirūt:Dār al-Fikr, 1994), h. 344-355

${ }^{17}$ Al-T Tabarī, Tafsīr al-Tabarī, Vol. 3 (Beirūt : Dār al-Kutub al-'Ilmiyyah, 1989), h. 577.

${ }^{18}$ Musda Mulia, Pandangan Islam Tentang Poligami (Jakarta : LKAJ-SP 1999), h. 34.

${ }^{19}$ Musda Mulia, Pandangan Islam Tentang Poligami , h. 32-33.

${ }^{20}$ Dalam Fikih Syafi'I dijelaskan pembagian malam kunjungan terhadap para istri
} 
fawāhidatan" menegaskan bahwa keraguan dalam bentuk ketidakmampuan berbuat "adil" kepada para wanita akan menjadi ganjalan dalam berpoligami.

Menurut kalangan penggiat hak perempuan, kesetaraan antara laki-laki dan perempuan dalam hukum domestic keluarga mutlak terjadi. Perempuan harus mendapatkan hak-hak mereka dalam hal sumber daya materi semisal pekerjaan, hak-hak kewarisan dan akses terhadap usaha kesejahteraan mereka dalam keluarga. Tuntutan ini dalam rangka terciptanya keadilan dalam keluarga dan distribusi kesejahteraan. Judith E Tucker, seorang professor sejarah pada Universitas Georgetown Amerika Serikat menginditifikasi jika dalam Islam telah terjadi perbedaan yang mencolok antara hukum yang bersumber dari Tuhan dengan implementasi di lapangan. Menurut Judith, Hukum Islam yang diyakini bersumber dari Tuhan Sang Maha Adil kiranya berbeda dalam praktek di lapangan. Judith membangun kongklusinya dari hasil penelitiannya di Nigeria yang mendapati seorang perempuan harus bertarung dengan ancaman hukuman mati hanya karena suaminya menolak mengakui anak yang dilahirkannya dengan tuduhan zina, begitupula seorang wanita penghibur terkemukan Mesir yang membuntuti suaminya ke sebuah flat dan menemukan bahwa suaminya sedang tidur bersama dengan perempuan lain yang telah dinikahi oleh suminya. Fakta lain adalah ketika mendapati 15 orang wanita Arab Saudi yang harus bertarung dengan maut hanya karena larangan polisi Arab Saudi meninggalkan sekolah yang sedang terbakar serta upaya sebuah dewan agama di India untuk menantang sebuah keputusan pemerintah menetapkan batas usia 18 tahun bagi calon pengantin perempuan. ${ }^{21}$ Keseluruhan kongklusi ini menurut Judith dibangun atas dasar panutan agama dan perintah agama, padahal implementasi demikian jauh dari keadilan hukum. Itu sebabnya, Judith kemudian banyak melakukan riset di Negara-negara Islam untuk menguji kebenaran implementasi ajaran Islam yang menurutnya sangat dalam.

Keadilan dalam menempatkan laki-laki dan perempuan dalam proses penciptaan menjadi sorotan kalangan Filosof untuk memberi saham kepada masing-masing demi terciptanya keseimbangan antara dua jenis kelamin yang berbeda. Ibu Sina memandang bahwa proses penciptaan berasal dari bentuk dan materi. Bentuk adalah sifat dari sesuatu dan bertindak sebagai prinsip atau penggagas perubahan, sedangkan materi adalah yang menerima perubahan. ${ }^{22}$ Ulasan Ibnu Sina tentang proses penciptaan dimaksudkan untuk memberi kesan bahwa terdapat peran yang seimbang antara dua jenis kelamin.

Dogondoutchi, sebuah daerah pedesaan di Nigeria setidaknya telah memperlihatkan konteks keadilan yang complang terhadap perempuan. Mariama, seorang gadis setempat yang menikah di usia 15 tahun sebagai istri kedua harus bergelut dengan kenyataan pahit kehilangan buah hatinya sebanyak 2 orang dari 11 orang anak yang dilahirkannya. Mariama adalah potret ibu rumah-tangga yang berjibaku dengan waktu untuk menyelematakan anak-

${ }^{21}$ Judith e. Tucker, Women, Family, and Gender in Islamic Law (Cet. I; New York: Cambridge University Press, 2008), h. 1. 76.

${ }^{22}$ Etin Anwar, Gender and Self in Islam (Cet. 1; New York: Taylor \& Francis e-Library, 2006), h. 
anaknya dari kematian di musim kekeringan yang menimpa Nigeria setiap tahun. Sementara di sisi lain, pemuka agama melarangnya untuk menggunakan kontrasepsi yang dianggap sebagai upaya Barat untuk mengebiri jumlah keturunan Muslim. Pada akhirnya, Mariama telah memilih untuk menggunakan kontrasepsi meski tidak sepengetahuan suaminya dan mendelegasikan hal serupa kepada anak-anak putrinya yang telah berumahtangga. Mariama telah mengalami jalan panjang ketidak adilan dalam hukum d omestic dan ada banyak Mariama-Mariama lain di luar sana yang berjuang untuk menyelematkan hidup dan anak-anaknya. ${ }^{23}$

Potret kelam poligami dalam dunia Islam telah membuka babak baru diskursus mengenai keselarasan perintah suci dalam Alquran tentang hal ini dengan fakta hidup yang diamalkan secara berbeda. Setidaknya, masih tersisa pertanyaan mendasar seputar poligami; apakah perbuatan hukum yang legal ini mengisyaratkan adanya keserasian dan keadilan dalam pengaktualisasiannya. Seperti perbuatan hukum lain, poligami harusnya tidak menyisakan ketidakadilan terhadap subjek maupun objek hukum sehingga apapun yang terjadi saat diimplementasikan tergambar sebagai keagungan pengamalan ajaran suci yang bersumber dari Tuhan.

Poligami juga telah menimbulkan keterkejutan hukum di Inggris ketika populasi umat Islam mulai berkembang pada paruh akhir abad ke 20 dimana hukum-hukum tradisional mengenai kekeluargaan telah dicabut. Hukum Islam melegalkan seorang laki-laki memiliki istri lebih dari satu, bahkan sampai empat dan hal ini merupakan suatu bentuk perlawanan terhadap hukum nasional yang menafikan praktek poligami. Medi Siadatan seorang pemilik restoran di Inggris, setidaknya menginginkan adanya jaminan terhadap istri-istri yang dipoligami oleh hukum Inggris Raya. Tentu saja apa yang diinginkan oleh Medi hampir mustahil, namun perjuangan kelompok muslim untuk melawan hukum Nasional Inggris dengan memasukkan Konvensi Eropah tentang hak azasi manusia ke dalam hukum domestik Inggris untuk pertamakalinya dianggap sebagai sebuah langkah hukum baru dalam kamus hukum Inggris. ${ }^{24}$ Mengacu pada fenomena ini, langkah strategis yang harus ditempuh oleh para pemikir hukum Islam adalah menempat kan hukum Islam sebagai hukum yang hidup di tengah masyarakat dengan tingkat moderasi dan modernisasi yang tinggi. Standar komitmen hukum Islam terhadap modernisasi mungkin menimbulkan gejolak penolakan dari kalangan konservatif, namun upaya ke arah itu mutlak dilakukan.

Tidak didapati satupun ayat dalam Alquran yang menjastifikasi ketidakadilan terhadap perempuan. Termasuk dalam konteks hubungan domestik keluarga sebab seorang laki-laki dan perempuan dalam sebuah keluarga berkedudukan sebagai pasangan. QS. Al-Nisa/4:34 mengisyaratkan keseimbangan dalam sebuah keluarga, namun terkadang ayat ini dimaknai oleh

${ }^{23}$ Adeline Masquelier, Women and Islamic Revival in a West African Town (Cet. I; Bloomington and Indianapolis: Indiana University Press, 2009), h. 275-277.

${ }^{24}$ Samuel Chapman, Polygamy, Bigamy and Human Rights Law (Cet. I; United States of America: Xlibris Corporation, 2001), h. 8-10. 
beberapa mufassir sebagai landasan hukum memperlihatkan hegemoni laki-laki atas perempuan. Syed Muhammad Ali mengadakan eksplorasi terhadap pendapat beberapa penafsir terkait makna al-rijālu qawwīmūna 'alā al-nisā dan ditemukan bahwa diantara sekian banyak penafsir, hanya Abū al-'Alā alMawdūdì yang memaknai bahwa ayat ini adalah indikator kelebihan laki-laki dalam penciptaan sehingga disinyalir memiliki keunggulan dibanding laki-laki. Itu sebabnya, Azizah al-Hibri menolak terjemahan ini dan mengatakan bahwa ayat ini bermakna laki-laki adalah pelindung bagi perempuan. ${ }^{25}$

Penjelmaan hak dan kewajiban dalam sebuah keluarga memunculkan berbagai macam versi mengenai kedudukan laki-laki dan perempuan dalam sebuah lembaga perkawinan. Jika dalam perkawinan monogami terdapat keselarasan dan kesetaraan hak, maka apakah dalam perkawinan poligami akan ada keadilan yang setara pula. Mungkin jawaban ini akan ditemukan pada hati sanubari masing-masing guna mengemas nilai keadilan di dalamnya.

\section{KESIMPULAN}

Kelompok Qadariyah dan Jabariyah telah terpola menjadi dua kelompok besar yang berseberangan dalam menyikapi perbuatan manusia. Kelompok Qadariyah memaknai perbuatan manusia sebagai jalan bagi Tuhan untuk berbuat adil kepada hamba-Nya sehingga Hamba tersebut diberi kebebasan untuk memilih perbuatan yang dipilihnya dengan demikian hamba tersebut dapat dituntut pertanggungjawaban. Sebaliknya Jabariyah memandang bahwa Tuhan Maha Berkehendak dan Maha Berkuasa dan dalam kekuasaan-Nya, Tuhan bias berbuat apasaja termasuk dalam menentukan siapa agen dalam perbuatan manusia. Itu sebabnya dalam pandangan Jabariyah, manusia diibaratkan bagai wayang yang digerakkan.

Sebagai hukum yang diturunkan oleh Tuhan, poligami memiliki unsur transedental yang kerap kali menimbulkan beragam penafsiran. Dalam konteks ini poligami menimbulkan suasana baru untuk mengungkit kembali nilai-nilai keadilan dalam perbuatan hukumnya. Jika manusia bertanggungjaawab atas perbuatannya sebagaimana Qadariyah, maka poligami seyogyanya memberi ruang keadilan bagi kaum perempuan, namun jika poligami hanyalah bermakna hak prerogative Tuhan menurunkan hukum, maka tuntutan atas keadilan dalam perbuatan hukum ini tak dapat dimunculkan mengingat hukum tersebut telah menjadi kehendak mutlak Tuhan.

Wallahu A'lam.

${ }^{25}$ Mohammad Ali Syed, The Position of Women in Islam A Progressive View (Cet. I; New York: State University of New York Press, 2004), h. 51-52. 


\section{DAFTAR PUSTAKA}

Ali Syed, Mohammad The Position of Women in Islam A Progressive View, Cet. I; New York: State University of New York Press, 2004

Al-Marāghī, Aḥmad Mușțafā. Tafsīral-Marāghi, Jilid V, t.t.:Dār al-Fikr,1974

Al-Muțahhari, Murtaḍa. al-'Adl al-Ilāhī, terj. Ke dalam Bahasa Arab oleh Muhammad Abd al-Mun'im al-Khaqani, Qumm, Iran: Maṭba'at alKhayyām, 1981

Al-Nabrāwī, Khadijah. Mawsūuha al-Huqūq fí al-Islām Mesir: Dār al-Salām, 2006

Al-Ṭabarī, Tafsìr al-Ṭabarī, Vol. 3, Beirūt : Dār al-Kutub al-'Ilmiyyah, 1989

Al-Zamaskhsyarī, Al-Kasysyāf 'an Haqāiq Gawāmid al-Tanzīl wa 'Uyūn al-Aqāwil fì

Wujūḥ al-Ta'wīl, Juz III, Mesir: Dār al-Kutub al-'Ilmiyyah, 1998

Amīn, Aḥmad. Duhā al-Islām Juz III Mesir: Maktabah al-Nahḍah, t.thal-

Anwar, Etin. Gender and Self in Islam, Cet. 1; New York: Taylor \& Francis eLibrary, 2006

Barlas, Asma. Believing Women in IslamUnreadingPatriarchal Interpretation of The Qur'ān, Cet. I; United States Of America: University of Texas Press, 2002.

Chapman, Samuel. Polygamy, Bigamy and Human Rights Law, Cet. I; United States of America: Xlibris Corporation, 2001.

Ibnu Hisyām, Sirah al-Nabawiyah Kairo: Dār al-Tawfiqiyah, 1975

Kementrian Agama RI. Alquran dan Terjemahnya Semarang: Toha Putera, 2014

Masquelier, Adeline. Women and Islamic Revival in a West African Town, Cet. I; Bloomington and Indianapolis: Indiana University Press, 2009

Mulia, Musda. Pandangan Islam Tentang Poligami Jakarta : LKAJ-SP 1999

Nasution, Harun. Teologi Islam; Sejarah, Analisa Perbandingan Jakarta: UI Press, 1989

Riḍa, Muhammad Rāsyid, Tafsīr al-Manār vol.4, Beirūt:Dār al-Fikr, 1994

Shihab, M. Quraish. Wawasan Alquran, Edisi Baru, Cet. II; Bandung: Mizan, 2007

Souaiaia, Ahmed E., Contesting Justice Women, Islam, Law, and Society Cet. I; New York: State University of New York Press, Albany, 2008

Syahrastānī, Muhammad Ibn al-Karīm. al-Milal wa Nihal Beirūt: Dār al-Fikr, t.th

Tucker, Judith e. Women, Family, and Gender in Islamic Law Cet. I; New York: Cambridge University Press, 2008 